\title{
Effect of surfactants and temperature on germination and vegetative growth of Beauveria bassiana
}

\author{
Lizzy A. Mwamburi ${ }^{1}$, Mark D. Laing ${ }^{1}$, Ray M. Miller ${ }^{2}$ \\ ${ }^{1}$ School of Agricultural Sciences and Agribusiness, University of KwaZulu-Natal, \\ Pietermaritzburg, South Africa. \\ ${ }^{2}$ School of Biological and Conservation Sciences, University of KwaZulu-Natal, \\ Pietermaritzburg, South Africa.
}

Submitted: October 9, 2013; Approved: June 6, 2014.

\begin{abstract}
Three non-ionic surfactants: Tween20, Tween 80 and Breakthru ${ }^{\circledR}$ were screened for their effects on spore germination and mycelial growth rates and for their influence on three isolates of Beauveria bassiana spore germination at various temperatures. Tween 20 and Tween 80 were compatible with all the $B$. bassiana isolates in the germination studies, but inhibited germination at higher surfactant concentrations, irrespective of the conidial concentrations. Breakthru ${ }^{\circledR}$ had an inhibitory effect on germination even at the lowest concentration of $0.1 \%$ on all the $B$. bassiana isolates. The effects of the surfactants on spore germination did not correspond with their effects on colony growth. Conidial viability within the same formulation declined significantly with increases in temperature, irrespective of the surfactant. The optimal temperature for conidial germination of B. bassiana isolates was approximately $25^{\circ} \mathrm{C}$ with an upper limit at $30^{\circ} \mathrm{C}$. Isolate 7320 was identified as the least affected by the different surfactants. This isolate was able to germinate rapidly in a broad temperature range of $25-30{ }^{\circ} \mathrm{C}$ after $24 \mathrm{~h}$, this characteristic being an essential factor in controlling house fly populations in poultry houses.
\end{abstract}

Key words: Beauveria bassiana, surfactant, temperature, conidia germination, mycelial growth.

\section{Introduction}

House flies (Musca domestica L.) are major pests of poultry production systems in tropical and subtropical countries. Up to now, control strategies have been dependent on the use of synthetic chemical insecticides. However, recognition of associated problems such as non-target effects, environmental pollution as well as the high economic costs involved, have prompted the development of alternative control strategies. Beauveria bassiana (Balsama) Vuillemin is one of the most ubiquitous and extensively studied entomopathogenic fungi (Feng et al., 1994; Hajek and St. Leger, 1994). This entomopathogenic fungus has also been intensively studied with the aim of development of commercial mycopesticides for the management of insect pests (Burges, 1998; Butt et al., 2001).
In our previous investigations (Mwamburi et al., 2010), a number of B. bassiana isolates that showed high virulence to adult house flies were identified, but a range of factors need to be considered before selecting the isolates for further use. Prolonged conidial survival in the field would help to maximize mortality of target insects. However, prolonged exposure to high temperatures limits the survival of entomopathogenic fungi in the field (Benz, 1987; Carruthers et al., 1985; Ekesi et al., 1999; Fargues et al., 1992; Ferron et al., 1991; Roberts and Campbell, 1977; Vestergaard et al., 1995). The thermal constraints are not only as a result of ambient conditions, but also those achieved through host thermoregulation. For instance, some insects elevate their body temperature through basking in the sun (Chappell and Whitman, 1990) and such activity has been shown to reduce disease incidence of Entomophthora muscae (Cohn) Fres. in house flies (Wat-

Send correspondence to L.A. Mwamburi. School of Agricultural Sciences and Agribusiness, University of KwaZulu-Natal, 3209 Pietermaritzburg, South Africa. E-mail: lizzymwamburi@hotmail.com. 
son et al., 1993), Entomophaga grylli (Fres.) Batko (Carruthers et al., 1992), B. bassiana (Bals.) Vuill. (Inglis et al., 1996) and Metarhizium flavoviride Gams and Rozsypal (Fargues et al., 1997; Inglis et al., 1996) in acridids.

The surfactant used is also recognized as a critical component in assisting conidia of a pathogen to germinate and infect the target organism. Surfactants can have a range of effects on fungal spore germination and mycelial growth. Therefore there is need for careful evaluation for compatibility of surfactants with conidia prior to their use in formulations (Daoust, 1983). The selection of an surfactant can enhance the uptake and transport of fungal spores and therefore play an important role in increasing the efficacy of a biocontrol agent such as Beauveria. This aim of this study was to evaluate the effects of various surfactants on the germination and tolerance of Beauveria bassiana isolates (7320, 7569 and 7771) spores formulated at different conidial densities at three different temperatures regimes.

\section{Materials and Methods}

\section{Fungal isolates}

Three isolates of B. bassiana (Isolates 7320, 7569, 7771) were used in this study. These isolates were originally obtained from the Plant Protection Research Institute (Agricultural Research Council, 1134 Park Street, P.O. Box 8783 Hatfield, Pretoria 0001), Pretoria.

\section{Fungal cultures}

The fungi were grown on Sabourand Dextrose Agar (SDA) in Petri dishes and incubated for $10 \mathrm{~d}$ for fungal growth and conidial production. For viability tests, conidia were removed using a brush, suspended in distilled water and different surfactants, and vortexed for 2 min to produce a homogenous suspension. Conidia were mixed with surfactants prior to addition of water to obtain homogenous suspensions. The stock formulation of each concentration was filtered using a sterile muslin cloth. All conidial formulations had the dose adjusted to $10^{4}, 10^{5}, 10^{6}, 10^{7}$ and $10^{8}$ conidia $\mathrm{mL}^{-1}$ using a Neubauer's chamber.

\section{Surfactants}

Three surfactants (Tween20, Tween80 and Breakthru $^{\circledR}$ (Evonik Degussa Africa (Pty) Ltd. Co. New Rd, Halfway House 1682, South Africa)) were used to measure conidial germination and mycelial growth. Water was used as a control.

\section{Effects of different surfactants on Beauveria bassiana conidial viability}

A factorial design was set up consisting of three fungal isolates (Isolates 7320, 7569, and 7771), four conidial densities $\left(10^{5}, 10^{6}, 10^{7}\right.$ and $10^{8}$ conidia $\left.\mathrm{mL}^{-1}\right)$, three surfactants (Tween20, Tween80, Breakthru ${ }^{\circledR}$ ) and water as a con- trol, with five surfactant concentrations $(0,0.1,0.5,1$ and $5 \% \mathrm{v} / \mathrm{v}$ or $\mathrm{w} / \mathrm{v})$. The effects of surfactants on conidial germination was evaluated by incorporating surfactants directly into $1.5 \%$ water agar at $0,0.1,0.5,1$ and $5 \%(\mathrm{v} / \mathrm{v}$ or $\mathrm{w} / \mathrm{v}$ ). Agar discs (16 mm diameter) were then cut with a cork borer and placed onto supporting slides. Drops $(10 \mu \mathrm{L})$ of each conidial suspension were placed on the discs and spread evenly on the surface. The glass slides supporting the agar discs were placed in Petri dishes and incubated at approximately $21{ }^{\circ} \mathrm{C}$. After $24 \mathrm{~h}$ of incubation, $12.5 \mu \mathrm{L}$ of lactophenol-cotton blue were placed on the agar discs to arrest germination of conidia. A conidium was considered to have germinated when the length of the germtube was greater than its width, or when a sessile appressorium was produced. Several randomly selected fields of view were examined using a compound microscope until a total of 300 conidia per replicate had been assessed.

\section{Effects of different surfactants on Beauveria bassiana mycelial growth}

To measure mycelial growth, Petri dishes containing $20 \mathrm{~mL}$ PDA were amended with the same surfactant concentrations. Each dish was inoculated with a $6 \mathrm{~mm}$ diameter mycelial-agar plug obtained from the margin of a 7-day old culture. Dishes of each treatment were incubated for $10 \mathrm{~d}$ at constant dark at $21 \pm 1{ }^{\circ} \mathrm{C}$ and were removed at $48 \mathrm{~h}$ intervals for assessment of mycelial growth. Colony growth was recorded as mean perpendicular radius minus the diameter of the inoculum plug $(6 \mathrm{~mm})$.

\section{Effect of temperature on conidial germination}

To investigate the effect of temperature on conidial viability, a conidial suspension $(1 \mathrm{~mL})$ of each isolate $\left(10^{8}\right.$ conidia $\mathrm{mL}^{-1}$ ) was mixed with the surfactant and plated onto Petri dishes containing $20 \mathrm{~mL}$ PDA that were amended with the same surfactant. Plates were incubated in the dark at 25,30 and $35 \pm 1{ }^{\circ} \mathrm{C}$. Conidial viability tests were carried out with readings after $24 \mathrm{~h}$ and $48 \mathrm{~h}$ of incubation at $21{ }^{\circ} \mathrm{C}$ to allow time for conidia recovery from any adverse effects caused by temperature. Conidia were observed at 400x magnification and germination was recorded when the germ tube was visible. A minimum of 300 conidia per plate were evaluated.

\section{Statistical analysis}

The viability experiments had factorial designs with four factors. Analysis of variance (ANOVA) on conidial viability data was performed using GENSTAT, after transforming the percent germination data to Arcsine $\sqrt{ }(\% / 100)$ for normal distribution and homogeneity of variances (Sokal and Rohlf, 2012). This data is presented in the tables together with the untransformed means and were used in statistical analysis. Means were compared using Least Significant Difference (LSD). The results are presented both as untransformed and transformed data. 
The mycelial growth rate $\left(\mathrm{K}_{\mathrm{r}}\right)$ was calculated in millimetres per $24 \mathrm{~h}$ using simple linear regression and was used as the main parameter to evaluate the influence of temperature on fungal growth (Fargues et al., 1992). ANOVA was performed on the growth rates and means were compared using LSD.

\section{Results}

\section{Effects of different surfactants on Beauveria bassiana conidial viability}

Conidial concentration, surfactants, surfactant concentration and the interaction of these factors affected germination of conidia $(\mathrm{p}<0.001)$ of isolates of $B$. bassiana. The germination of conidia of three $B$. bassiana isolates in response to the three surfactants (Tween20, Tween80 and Breakthru $^{\mathbb{B}}$ ), surfactant concentration and conidial densities are shown in Figure 1. The surfactants generally inhibited germination at higher surfactant concentrations and at all conidial concentrations for all the three isolates of Beauveria (Figure 1). Tween20 showed varied effects on the three Beauveria isolates. For Isolate 7320, conidial germination remained fairly constant initially, declining by at least $30 \%$ as the concentration of Tween 20 increased up to $1 \%$, after which there was a more obvious decrease and germination dropped to $66,56,49$ and $42 \%$ in $10^{5}, 10^{6}, 10^{7}$ and $10^{8}$ conidia $\mathrm{mL}^{-1}$ concentrations respectively (Figure 1 ).

For Isolate 7569, the addition of Tween 20 did not stimulate conidial germination, even at low concentrations of $0.1 \%$. Instead, the addition of Tween 20 resulted in an immediate rapid decline in germination, e.g., at low conidial concentrations of $10^{5}, 10^{6}$ and $10^{7}$ conidia $\mathrm{mL}^{-1}$, germination was reduced by $40-50 \%$, while at a higher conidial concentration of $10^{8}$, germination was reduced by approximately $20 \%$ with a concentration of $0.1 \%$ Tween 20 .
Increases of Tween 20 concentrations beyond $0.1 \%$ resulted in a gradual decline in germination (Figure 1). In the case of Isolate 7771, Tween20 stimulated conidial germination at $0.1 \%$ concentration, but inhibited conidial germination at higher concentrations (Figure 1).

Tween 80 inhibited germination of Isolate 7320 at $0.1 \%$ concentration, but stimulated germination at 0.5 and $1.0 \%$ concentrations. For example, at conidial concentrations of $10^{6}, 10^{7}$ and $10^{8}$, Tween 80 had a stimulatory effect on germination, increasing by approximately $10 \%$ for $10^{7}$ and $10^{8}$ and $30 \%$ for $10^{6}$ conidial concentrations. The same surfactant concentrations had no effect on the $10^{5}$ conidial concentrations. Conidial germination dropped sharply with a $1.0 \%$ Tween 80 concentration, for all concentrations of conidia. Addition of $0.1 \%$ Tween 80 had a slight stimulatory effect on germination of Isolate 7569 conidia, but concentrations between $0.1-0.5 \%$ had substantial inhibitory effects on germination. Tween 80 concentrations higher than $0.5 \%$ had slight (5-12\%) stimulatory effects on germination. For the Isolate $7771,0.1 \%$ concentration of Tween 80 stimulated germination; however, surfactant concentrations higher than $0.1 \%$ had inhibitory effects on conidial germination (Figure 1).

Breakthru $^{\circledR}$ had an inhibitory effect on all the B. bassiana isolates at all concentrations. For Isolate 7320 , although the $0.1 \%$ concentration caused a slight inhibition of germination, a significant decline of conidial germination was observed as Breakthru ${ }^{\circledR}$ concentration was increased, resulting in approximately $70 \%$ inhibition of germination with the $5 \%$ Breakthru $^{\circledR}$ concentration. Although addition of Breakthru ${ }^{\circledR}$ inhibited conidial germination of Isolates 7569 and 7771, the trends differed from that observed with 7320 . For both Isolates 7569 and 7771, addition of Breakthru ${ }^{\circledR}$ at a low concentration of $0.1 \%$ resulted
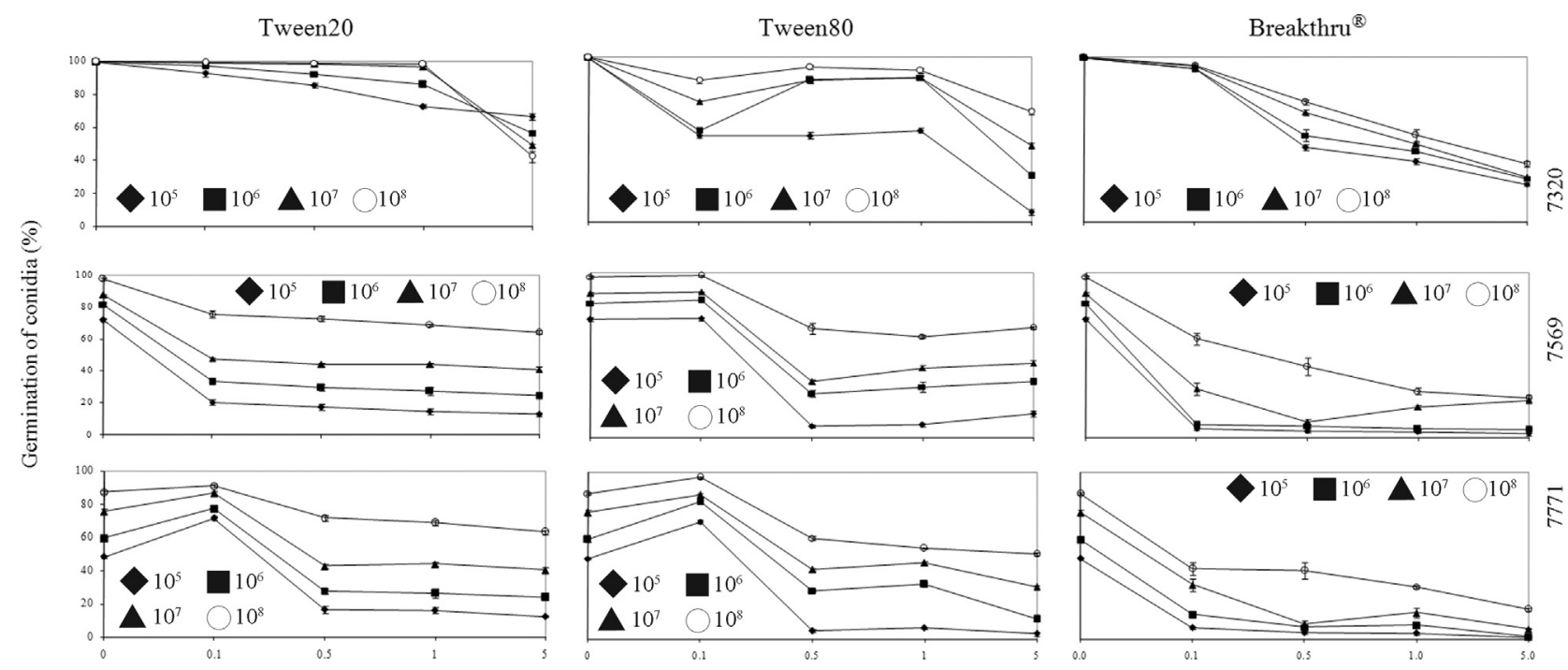

Figure 1 - Effects of Tween20, Tween 80 and Breakthru ${ }^{\circledR}$ at various concentrations $(0,0.1,0.5,1$ and $5 \%)$ on the germination of conidia of three isolates of Beauveria bassiana at four conidial densities. 
in an immediate rapid drop of $>40 \%$ of conidial germination (Figure 1).

There were significant differences in germination among concentrations of the similar surfactants within the same conidial concentration for all the three isolates $(\mathrm{p}<0.001)$.

\section{Effects of different surfactants on Beauveria bassiana mycelial growth rate}

Isolates, surfactants and surfactant concentration and their interactions except isolate $\mathrm{x}$ surfactant $\mathrm{x}$ surfactant concentration had significant effects $(\mathrm{p}<0.05)$ on radial mycelial growth $\left(\mathrm{K}_{\mathrm{r}}\right)$ of isolates of $B$. bassiana. Tween 20 caused a non-significant mycelial growth reduction at $0.1 \%$ concentration in 7320 and a significant inhibition after $0.1 \%$ concentration that remained fairly constant at higher concentrations (Table 1). While an increase in concentration of Tween 20 presented significant reductions in Isolate 7569 , fewer differences were observed in Isolate 7771 (Table 1).
The effect of Tween 80 on the $\mathrm{K}_{\mathrm{r}}$ of the $B$. bassiana isolates was similar to that of conidial germination. The growth of Isolate 7320 was inhibited by $0.1 \%$ concentration of Tween 80 , stimulated at 0.5 and $1.0 \%$ concentrations and inhibited at concentrations higher than $1.0 \%$. Tween 80 inhibited growth of Isolate 7569 at $0.1 \%$ concentration and these were non-significant reductions at higher concentrations. Growth of Isolate 7771 was not affected by Tween 80 concentrations of up to $1 \%$ (Table 1).

For all the $B$. bassiana isolates, moderate reductions in mycelial growths were observed as a result of increasing concentrations of Breakthru ${ }^{\circledR}$. However, fewer differences were observed for Isolate 7771 compared to Isolates 7320 and 7569 (Table 1).

\section{Effect of temperature of germination}

The effects of surfactant, temperature, incubation time and the interaction of these factors significantly affected $(\mathrm{p}<0.001)$ the conidial germination of the various isolates of $B$. bassiana. Comparisons of the mean conidial germination levels between at each temperature within

Table 1 - Effects of five concentrations of three surfactants (Tween20, Tween 80 and Breakthru $\left.{ }^{\circledR}\right)$ on the radial growth rate $\left(K_{\mathrm{r}} \pm\right.$ se) of three isolates (7320, 7569 and 7771) of Beauveria bassiana.

\begin{tabular}{|c|c|c|c|c|}
\hline \multirow[t]{3}{*}{ Surfactant } & \multirow[t]{3}{*}{ Surfactant concentration $(\%)$} & \multicolumn{3}{|c|}{ Radial mycelial growth rate $\left(\mathrm{K}_{\mathrm{r}}\right.$ in $\mathrm{mm}$ day $\left.^{-1}\right) \pm \mathrm{se}$} \\
\hline & & \multicolumn{3}{|c|}{ Isolates } \\
\hline & & 7320 & 7569 & 7771 \\
\hline \multirow[t]{5}{*}{ Tween 20} & 0 & $1.08 \pm 0.08^{\mathrm{f}}$ & $1.46 \pm 0.06^{\mathrm{f}}$ & $1.13 \pm 0.08^{b}$ \\
\hline & 0.1 & $1.02 \pm 0.07^{\mathrm{def}}$ & $1.17 \pm 0.1^{\mathrm{de}}$ & $1.54 \pm 0.3^{\mathrm{c}}$ \\
\hline & 0.5 & $0.8 \pm 0.09^{\mathrm{ab}}$ & $1.22 \pm 0.17^{\mathrm{e}}$ & $1.11 \pm 0.09^{b}$ \\
\hline & 1 & $0.9 \pm 0.09^{\mathrm{bcd}}$ & $1.08 \pm 0.13^{\mathrm{cd}}$ & $1.13 \pm 0.09^{b}$ \\
\hline & 5 & $0.8 \pm 0.09^{\mathrm{ab}}$ & $0.88 \pm 0.09^{b}$ & $1.10 \pm 0.11^{\mathrm{b}}$ \\
\hline \multirow[t]{5}{*}{ Tween 80} & 0 & $1.08 \pm 0.08^{\mathrm{f}}$ & $1.46 \pm 0.06^{\mathrm{f}}$ & $1.13 \pm 0.08^{b}$ \\
\hline & 0.1 & $0.96 \pm 0.1^{\text {cdef }}$ & $1.07 \pm 0.13^{\mathrm{c}}$ & $1.07 \pm 0.09^{\mathrm{ab}}$ \\
\hline & 0.5 & $1.04 \pm 0.12^{\text {def }}$ & $1.12 \pm 0.07^{\mathrm{cd}}$ & $1.05 \pm 0.07^{\mathrm{ab}}$ \\
\hline & 1 & $1.06 \pm 0.12^{\mathrm{ef}}$ & $1.13 \pm 0.1^{\mathrm{cd}}$ & $1.11 \pm 0.09^{\mathrm{a}}$ \\
\hline & 5 & $0.87 \pm 0.1^{\mathrm{bc}}$ & $1.12 \pm 0.13^{\mathrm{cd}}$ & $0.86 \pm 0.15^{a b}$ \\
\hline \multirow[t]{5}{*}{ Breakthru $^{\circledR}$} & 0 & $1.08 \pm 0.08^{\mathrm{f}}$ & $1.46 \pm 0.06^{\mathrm{f}}$ & $1.13 \pm 0.08^{b}$ \\
\hline & 0.1 & $0.96 \pm 0.12^{\text {cdef }}$ & $1.26 \pm 0.14^{\mathrm{e}}$ & $1.01 \pm 0.09^{\mathrm{ab}}$ \\
\hline & 0.5 & $1.04 \pm 0.13^{\mathrm{def}}$ & $1.11 \pm 0.13^{\mathrm{cd}}$ & $0.86 \pm 0.1^{\mathrm{ab}}$ \\
\hline & 1 & $0.92 \pm 0.14^{\text {bcde }}$ & $1.13 \pm 0.13^{\mathrm{cd}}$ & $0.84 \pm 0.08^{a b}$ \\
\hline & 5 & $0.69 \pm 0.09^{\mathrm{a}}$ & $0.72 \pm 0.1^{\mathrm{a}}$ & $0.68 \pm 0.06^{\mathrm{a}}$ \\
\hline F-ratio & & 55.28 & 67.15 & 34.23 \\
\hline $\mathrm{p}$-value & & $<0.001$ & $<0.001$ & $<0.001$ \\
\hline LSD & & 0.07 & 0.053 & 0.06 \\
\hline$\% \mathrm{CV}$ & & 11.5 & 7 & 6.5 \\
\hline Effect & & $* *$ & $* *$ & $* *$ \\
\hline
\end{tabular}

Means followed by the same letter within the same column are not significantly different ( $\mathrm{p}>0.05)$; F and $\mathrm{p}$ values after square root-arcsine transformation; ** Significant at $\mathrm{p} \leq 0.001$. 
each surfactant and between the isolates within each exposure time, 24 and $48 \mathrm{~h}$ after incubation are shown in Table 2. Factorial analysis of variance revealed more significant differences among surfactants at $24 \mathrm{~h}$ than $48 \mathrm{~h}$. Conidial viability within the same formulation declined significantly with increases in temperature, irrespective of formulation. This effect was more pronounced for Isolate 7771 and less prominent for Isolate 7320 (Table 2).

All the isolates showed more than $90 \%$ germination after $48 \mathrm{~h}$ at all temperatures. At a temperature of $30 \pm 1^{\circ} \mathrm{C}$, $<40 \%$ conidial germination was observed in all surfactants for the tested isolates, except Isolate 7320. With this isolate $>75 \%$ germination was observed at $30^{\circ} \mathrm{C}$ with all the sur- factants (Table 2). No delay in germination was observed at this temperature compared to germination at $25{ }^{\circ} \mathrm{C}$. At a temperature of $35^{\circ} \mathrm{C}$, all the isolates showed a significant delay or decrease in relative percentage germination after $24 \mathrm{~h}$ but reached $>90 \%$ after $48 \mathrm{~h}$. At a temperature of $35{ }^{\circ} \mathrm{C}$, all $\mathrm{B}$. bassiana isolates failed to germinate within $24 \mathrm{~h}$. Only Isolate 7320 germinated, but the levels of germination were $0.18,0.04$ and $0.04 \%$ in water, Tween 20 and Tween 80 , respectively.

The effect of water on germination can be separated into different responses with increasing temperature. While high germination levels were obtained with Isolate 7320 at $25^{\circ} \mathrm{C}$, Isolates 7569 and 7771 exhibited moderate germina-

Table 2 - Conidial viability ( $\% \pm \mathrm{se})$ of three isolates of Beauveria bassiana in different surfactants, $24 \mathrm{~h}$ and $48 \mathrm{~h}$ after incubation at three temperatures $\left(25,30\right.$ and $\left.35^{\circ} \mathrm{C}\right)$

\begin{tabular}{|c|c|c|c|c|c|c|c|}
\hline \multicolumn{8}{|c|}{ Mean germination of conidia (\%) } \\
\hline \multicolumn{8}{|c|}{ Isolates } \\
\hline \multirow[b]{2}{*}{ Surfactant } & \multirow[b]{2}{*}{ Temperature } & \multicolumn{2}{|c|}{7320} & \multicolumn{2}{|c|}{7569} & \multicolumn{2}{|c|}{7771} \\
\hline & & $24 \mathrm{~h}$ & $48 \mathrm{~h}$ & $24 \mathrm{~h}$ & $48 \mathrm{~h}$ & $24 \mathrm{~h}$ & $48 \mathrm{~h}$ \\
\hline \multirow[t]{3}{*}{ Water } & 25 & $\begin{array}{c}98.4 \pm 0.51 \\
(1.46)^{\mathrm{e}}\end{array}$ & $\begin{array}{c}99.2 \pm 0.37 \\
\quad(1.50)^{\mathrm{a}}\end{array}$ & $\begin{array}{c}61.0 \pm 3.32 \\
(0.90)^{\mathrm{e}}\end{array}$ & $\begin{array}{c}98.6 \pm 0.51 \\
\quad(1.47)^{\mathrm{a}}\end{array}$ & $\begin{array}{c}63.8 \pm 3.46 \\
(0.93)^{\mathrm{g}}\end{array}$ & $\begin{array}{c}98.6 \pm 0.51 \\
\quad(1.47)^{\mathrm{a}}\end{array}$ \\
\hline & 30 & $\begin{array}{c}77.2 \pm 0.86 \\
(1.07)^{\mathrm{d}}\end{array}$ & $\begin{array}{c}98.4 \pm 0.51 \\
\quad(1.46)^{\mathrm{a}}\end{array}$ & $\begin{array}{c}0.80 \pm 0.12 \\
(0.09)^{\mathrm{d}}\end{array}$ & $\begin{array}{c}98 \pm 0.32 \\
(1.43)^{\mathrm{a}}\end{array}$ & $\begin{array}{c}48.4 \pm 1.08 \\
\quad(0.77)^{\mathrm{d}}\end{array}$ & $\begin{array}{c}98.4 \pm 0.51 \\
\quad(1.46)^{\mathrm{a}}\end{array}$ \\
\hline & 35 & $\begin{array}{c}0.18 \pm 0.09 \\
(0.04)^{\mathrm{a}}\end{array}$ & $\begin{array}{c}98.4 \pm 0.40 \\
\quad(1.46)^{\mathrm{a}}\end{array}$ & $0 \pm 0(0)^{\mathrm{a}}$ & $\begin{array}{c}95.4 \pm 1.44 \\
(1.36)^{\mathrm{a}}\end{array}$ & $0 \pm 0(0)^{\mathrm{a}}$ & $\begin{array}{c}98.4 \pm 0.51 \\
\quad(1.46)^{\mathrm{a}}\end{array}$ \\
\hline \multirow[t]{3}{*}{ Tween20 } & 25 & $\begin{array}{c}98.4 \pm 0.51 \\
(1.46)^{\mathrm{e}}\end{array}$ & $\begin{array}{c}98.6 \pm 0.40 \\
\quad(1.47)^{\mathrm{a}}\end{array}$ & $\begin{array}{c}34.6 \pm 1.86 \\
(0.63)^{\mathrm{d}}\end{array}$ & $\begin{array}{c}98 \pm 0.32 \\
(1.43)^{\mathrm{a}}\end{array}$ & $\begin{array}{l}57.2 \pm 3.65 \\
\quad(0.86)^{\mathrm{i}}\end{array}$ & $\begin{array}{c}96.8 \pm 1.77 \\
(1.42)^{\mathrm{a}}\end{array}$ \\
\hline & 30 & $\begin{array}{c}86.8 \pm 1.07 \\
(1.20)^{\mathrm{cd}}\end{array}$ & $\begin{array}{c}98.2 \pm 0.37 \\
\quad(1.44)^{\mathrm{a}}\end{array}$ & $\begin{array}{c}27.8 \pm \\
1.39(0.55)^{\mathrm{de}}\end{array}$ & $\begin{array}{c}97.4 \pm 0.68 \\
(1.41)^{\mathrm{a}}\end{array}$ & $\begin{array}{c}38.6 \pm 2.73 \\
(0.67)^{\mathrm{de}}\end{array}$ & $\begin{array}{c}95.6 \pm 1.5 \\
(1.37)^{\mathrm{a}}\end{array}$ \\
\hline & 35 & $\begin{array}{c}0.04 \pm 0.02 \\
(0.01)^{\mathrm{a}}\end{array}$ & $\begin{array}{c}98.6 \pm 0.40 \\
(1.47)^{\mathrm{a}}\end{array}$ & $0 \pm 0(0)^{\mathrm{a}}$ & $\begin{array}{c}95.2 \pm 1.39 \\
(1.36)^{\mathrm{a}}\end{array}$ & $0 \pm 0(0)^{\mathrm{a}}$ & $\begin{array}{c}92.4 \pm 2.18 \\
\quad(1.30)^{\mathrm{a}}\end{array}$ \\
\hline \multirow[t]{3}{*}{ Tween 80} & 25 & $\begin{array}{c}98.0 \pm 0.95 \\
(1.46)^{\mathrm{e}}\end{array}$ & $\begin{array}{c}98.8 \pm 0.37 \\
\quad(1.47)^{\mathrm{a}}\end{array}$ & $\begin{array}{c}29.4 \pm 3.14 \\
\quad(0.57)^{\mathrm{f}}\end{array}$ & $\begin{array}{c}97.8 \pm 0.37 \\
\quad(1.42)^{\mathrm{a}}\end{array}$ & $\begin{array}{c}75.2 \pm 1.59 \\
(1.05)^{\mathrm{h}}\end{array}$ & $\begin{array}{c}98 \pm 0.55 \\
(1.44)^{\mathrm{a}}\end{array}$ \\
\hline & 30 & $\begin{array}{c}83.0 \pm 3.30 \\
\quad(1.15)^{\mathrm{bc}}\end{array}$ & $\begin{array}{c}98.2 \pm 0.20 \\
\quad(1.44)^{\mathrm{a}}\end{array}$ & $\begin{array}{c}31.2 \pm 1.85 \\
(0.59)^{\mathrm{b}}\end{array}$ & $\begin{array}{c}95.2 \pm 1.39 \\
\quad(1.36)^{\mathrm{a}}\end{array}$ & $\begin{array}{c}40 \pm 3.54 \\
(0.68)^{\mathrm{f}}\end{array}$ & $\begin{array}{c}98.8 \pm 0.37 \\
(1.47)^{\mathrm{a}}\end{array}$ \\
\hline & 35 & $\begin{array}{c}0.04 \pm 0.02 \\
(0.01)^{\mathrm{ab}}\end{array}$ & $\begin{array}{c}98.2 \pm 0.37 \\
(1.44)^{\mathrm{a}}\end{array}$ & $0 \pm 0(0)^{\mathrm{a}}$ & $95 \pm 1.3(1.35)^{\mathrm{a}}$ & $0 \pm 0(0)^{\mathrm{a}}$ & $\begin{array}{c}98.8 \pm 0.37 \\
\quad(1.47)^{\mathrm{a}}\end{array}$ \\
\hline \multirow[t]{3}{*}{ Breakthru $^{\circledR}$} & 25 & $\begin{array}{c}97.2 \pm 0.86 \\
(1.42)^{\mathrm{e}}\end{array}$ & $\begin{array}{c}98.6 \pm 0.60 \\
\quad(1.48)^{\mathrm{a}}\end{array}$ & $\begin{array}{c}29.8 \pm \\
1.77(0.58)^{\mathrm{de}}\end{array}$ & $\begin{array}{c}97.0 \pm 0.32 \\
\quad(1.4)^{\mathrm{a}}\end{array}$ & $\begin{array}{c}21.6 \pm 2.09 \\
(0.48)^{\mathrm{c}}\end{array}$ & $\begin{array}{c}95.8 \pm 1.59 \\
\quad(1.38)^{\mathrm{a}}\end{array}$ \\
\hline & 30 & $\begin{array}{c}87.4 \pm 2.50 \\
(1.22)^{\mathrm{bc}}\end{array}$ & $\begin{array}{c}98.4 \pm 0.51 \\
\quad(1.46)^{\mathrm{a}}\end{array}$ & $\begin{array}{c}7.0 \pm 0.95 \\
(0.27)^{\mathrm{c}}\end{array}$ & $\begin{array}{c}95.0 \pm 1.38 \\
\quad(1.35)^{\mathrm{a}}\end{array}$ & $\begin{array}{c}15 \pm 1.92 \\
(0.39)^{\mathrm{b}}\end{array}$ & $\begin{array}{c}98.2 \pm 0.37 \\
\quad(1.44)^{\mathrm{a}}\end{array}$ \\
\hline & 35 & $0 \pm 0(0)^{\mathrm{ab}}$ & $\begin{array}{c}98.0 \pm 0.32 \\
\quad(1.43)^{\mathrm{a}}\end{array}$ & $0 \pm 0(0)^{\mathrm{a}}$ & $\begin{array}{c}93.8 \pm 1.02 \\
\quad(1.32)^{\mathrm{a}}\end{array}$ & $0 \pm 0(0)^{\mathrm{a}}$ & $\begin{array}{c}97.2 \pm 0.73 \\
\quad(1.41)^{\mathrm{a}}\end{array}$ \\
\hline F-ratio & & 2.52 & 0.29 & 104.68 & 0.41 & 30.15 & 1.35 \\
\hline p-value & & 0.034 & 0.941 & $<0.001$ & 0.868 & $<0.001$ & 0.255 \\
\hline LSD & & 0.081 & 0.072 & 0.053 & 0.068 & 0.067 & 0.093 \\
\hline$\% \mathrm{CV}$ & & 7.2 & 3.9 & 12 & 3.8 & 10 & 5.1 \\
\hline Effect & & $*$ & NS & $* *$ & NS & $* *$ & NS \\
\hline
\end{tabular}

Values in parenthesis are square-root arcsine transformed.

Means followed by the same small letter within the same column are not significantly different at $\mathrm{p}<0.05$.

*Significant at $\mathrm{p}<0.05 ; * *$ Significant at $\mathrm{p} \leq 0.001 ; \mathrm{NS}$ - Not significant. 
tion levels. Temperature of $30^{\circ} \mathrm{C}$ reduced conidial germination of Isolates 7320 and 7771 by $20 \%$, and even less for Isolate 7569.

Tween 20 and Tween 80 stimulated germination of Isolate 7320 at $25^{\circ} \mathrm{C}$, but inhibited germination of Isolates 7569 and 7771 at the same temperature. Breakthru ${ }^{\circledR}$ showed a similar trend to Tween 20 and Tween 80 on Isolate 7320. However, Breakthru ${ }^{\circledR}$ caused severe inhibition $(<30 \%$ germination) of Isolates 7569 and 7771 , even at a temperature of $25^{\circ} \mathrm{C}$.

\section{Discussion}

While it is well documented that conidia of entomopathogenic fungi can germinate in surfactants, the viability of conidia may also be influenced by surfactant type (Boucias and Pendland, 1991; Boyette et al., 1996; Milner et al., 1991; Prasad, 1994). This study has shown that not only was conidial germination affected by the surfactant but also by the surfactant concentration and conidial concentration. The three surfactants tested had different effects on the viability of conidia and mycelial growth. However, in both studies, there were enough exceptions to conclude that the concentration should be checked for individual surfactants and individual isolates.

Our study generally showed that it is better to use low or moderate concentrations of surfactants than high concentrations in order to avoid reduced conidial germination. In no case did the use of the three selected surfactants result in improved germination in comparison to applying $B$. bassiana in water. The greatest germination occurred at the lowest surfactant concentrations. Although, B. bassiana proved to be an effective biocontrol agent of house flies in our previous studies (Mwamburi et al., 2010), addition of surfactants at low concentrations or by combining the surfactants, the efficacy of B. bassiana may still be increased, resulting in improved reliability. Similar observations were noted by Zhang et al. (2003). For example, Tween20, which is commonly used for initial screening of different fungi (Boyette et al., 1996), promoted germination at low surfactant concentration of $<1 \%$ in Isolate 7320 , inhibited germination of 7569 at all concentrations tested and lowered germination at concentrations higher than $0.1 \%$ for Isolate 7771. Furthermore, it did not stimulate mycelial growth of any of the $B$. bassiana isolates except for Isolate 7771 at $0.1 \%$ concentration. Germination of Isolate 7320 was unaffected by Tween 80 up to a concentration of $1 \%$ and then decreased significantly at higher concentrations. Isolates 7569 and 7771 were more sensitive to Tween 80 . Not all of the surfactants were compatible with B. bassiana isolates in vitro. The Breakthru ${ }^{\circledR}$ series were inhibitory to all the isolates at all concentrations, confirming results of Milner et al. (1991), who described toxic effects for various wetting agents.

Tween 20 increased mycelial growth of Isolate 7771 at $0.1 \%$, while it decreased mycelial growth of all the other isolates. Tween80 and Breakthru ${ }^{\circledR}$ failed to stimulate mycelial growth of any of the B. bassiana isolates. Greater germination was achieved with higher conidial concentrations. This relationship was checked because with similar fungi such as Colletotrichum spp., spore germination can be inhibited by high spore densities (Zhang et al., 2003). The observations of higher germination rates with higher conidial densities in this study were consistent with our earlier observations and with other reports related to dosemortality related studies of $B$. bassiana (Devi et al., 2005; Kaaya and Munyinyi, 1995; Lekimme et al., 2006; Santoro et al., 2008; Watson et al., 1993). In poultry houses and the field, inoculum at high densities are sprayed to target house flies and high germination rates of the inoculum may increase the overall effectiveness of the biocontrol agent.

The optimal temperature for conidial germination of B. bassiana isolates was approximately $25^{\circ} \mathrm{C}$, with an upper limit at $30^{\circ} \mathrm{C}$. A temperature of $25^{\circ} \mathrm{C}$ was reported to be optimal for B. bassiana by Fargues et al. (1992). In our study, all isolates showed $>90 \%$ conidial germination after $24 \mathrm{~h}$ of incubation at $21{ }^{\circ} \mathrm{C}$. Previous studies have shown that $B$. bassiana is mesophilic, capable of growth at a wide temperature range $\left(8-35{ }^{\circ} \mathrm{C}\right)$ with a maximum thermal threshold for growth at $37^{\circ} \mathrm{C}$ (Fargues et al., 1997). High temperatures retarded the conidial germination process in $B$. bassiana. Similar delays were found in the same $B$. bassiana isolates (Devi et al., 2005; Luz and Fargues, 1997). This delay is possibly associated with the need to repair damages before germination occurs, as was previously demonstrated in Bacillus spores (Nicholson et al., 2000).

Isolate 7320 was identified as the fungal strain that would be most suitable to formulate as a commercial product. Apart from being least affected by the different surfactants, this isolate was able to germinate rapidly in a broad temperature range of $25-30{ }^{\circ} \mathrm{C}$ after $24 \mathrm{~h}$, and this characteristic would be a crucial factor in suppressing house flies in poultry houses, where temperatures fluctuate markedly during the day and night. Also, house flies multiply rapidly during the hot summer season; hence, higher germination and growth rates of $B$. bassiana at higher temperatures would be beneficial for house fly control. In addition, studies have also shown that entomopathogenic fungi may experience elevated temperatures through host thermoregulation (Kalsbeek et al., 2001; Olesen, 1985; Watson et al., 1993). These authors reported that infected house flies were capable of elevating their body temperatures through habitat selection or basking in the sun within the first few days of infection and, if the temperatures were high for a sufficiently long period, infected flies would be able to cure themselves from disease (Kalsbeek et al., 2001; Olesen, 1985; Watson et al., 1993).

Our investigation was a laboratory study determining the influences of surfactants upon the first two stages, germination, and mycelial growth, which had some limitations. For example, conidial behaviour was only studied on 
agar plates, whereas ultimately infection occurs on an insect cuticle where texture, exudates, and microflora have a role in the pre-infection stages. Also, some surfactants may stimulate host defence responses and thereby reduce disease development in the host (Colson-Hanks and Deverall, 2000). Therefore, studies are recommended to evaluate the effect of these surfactants on pre-infection stages and post-infection disease development on the host house flies.

\section{Acknowledgments}

The authors acknowledge Third World Organization for Women in Science (TWOWS) for financial support.

\section{References}

Benz G (1987) Environment. In: Fuxa, J.R., Tanada, Y. (eds) Epizootiology of Insect Diseases. John Wiley, New York, pp 177-214.

Boucias DG, Pendland JC, (1991) Attachment of mycopathogens to cuticle. In: Cole GT, Hoch HC (eds). The Fungal Spore and Disease Initiation in Plants and Animals. Plenum Press, New York, pp 101-128.

Boyette CD, Quimby Jr. PC, Caesar AJ et al. (1996) Adjuvants, formulations, and spraying systems for improvement of mycoherbicides. Weed Technol 10:637-644.

Burges HD (1998) Formulation of mycoinsecticides. In: Burges, HD (ed) Formulation of Microbial Biopesticides: Beneficial Microorganisms, Nematodes and Seed Treatments. Kluwer Academic Publisher, Dordrecht, pp 132-185.

Butt TM, Jackson CW, Magan N (2001) Fungi as Biocontrol Agents: Progress, Problems and Potential. CAB International, Wallingford.

Carruthers RI, Feng Z, Robson DS et al. (1985) In vivo temperature-dependent development of Beauveria bassiana (Deuteromycotina: Hyphomycetes) mycosis of the European cornborer, Ostrinia nubilalis (Lepidoptera: Pyralidae). J Invertebr Pathol 46:305-311.

Carruthers RI, Larkin TS, Firstencel H (1992) Influence of thermal ecology on the mycosis of a rangeland grasshopper. Ecology 73:190-204.

Chappell MA, Whitman DW (1990) Grasshopper thermoregulation. In: Chapman, R (ed) Biology of Grasshoppers. Wiley, New York, pp 143-172.

Colson-Hanks ES, Deverall BJ (2000) Effect of 2, 6-dichloroisonicotinic acid, its formulation materials and benzothiadiazole on systemic resistance to alternaria leaf spot in cotton. Plant Pathol 49:171-178.

Daoust RA, Ward MG, Roberts DW (1983) Effect of formulation on the viability of Metarhizium anisopliae conidia. J Invertebr Pathol 41:151-160.

Devi KU, Sridevi V, Mohan CM et al. (2005) Effect of high temperature and water stress on in vitro germination and growth in isolates of the entomopathogenic fungus Beauveria bassiana (Bals.) Vuillemin. J Invertebr Pathol 88:181-189.

Devi KU, Rao CUM (2006) Allee effect in the infection dynamics of the entomopathogenic fungus Beauveria bassiana (Bals) Vuill. on the beetle, Mylabris pustulata. Mycopathologia 161:385-394.

Ekesi S, Maniania NK, Ampong-Nyarko F (1999) Effect of temperature on germination, radial growth and virulence of
Metarhizium anisopliae and Beauveria bassiana on Megalurothrips sjostedti. Biocontrol Sci Technol 9:177185.

Fargues J, Maniania NK, Delmas JC et al. (1992) Influence de la température sur la croissance in vitro d'hyphomycètes entomopathogènes. Agronomie 12:557-564.

Fargues J, Goettel MS, Smits N et al. (1997) Effect of temperature on vegetative growth of Beauveria bassiana isolates from different origins. Mycologia 89:389-392.

Feng MG, Poprawski TJ, Khatachatourians CG (1994) Production, formulation and application of the entomopathogenic fungus Beauveria bassiana for insect control: Current status. Biocontrol Sci Technol 4:3-34.

Ferron P, Fargues J, Riba G (1991) Fungi as microbial insecticides against pests. In: Arora DK, Ajello L, Mukerji KG (ed). Handbook of Applied Mycology. Volume 2. Marcel Dekker Inc., New York, pp 662-706.

Hajek AE, St. Leger RJ (1994) Interactions between fungal pathogens and insect hosts. Ann Rev Entomol 39:293-322.

Inglis GD, Johnson DL, Goettel MS (1996) Effects of temperature and thermoregulation on mycosis by Beauveria bassiana in grasshoppers. Biol Control 7:131-139.

Inglis CD, Johnson DL, Goettel MS (1997) Effects of temperature and sunlight on mycosis (Beauveria bassiana) (Hyphomycetes: Sympodulosporae) of grasshoppers under field conditions. Biol Control 26:400-409.

Kaaya GP, Munyinyi M (1995) Biocontrol potential of the entomogenous fungi Beauveria bassiana and Metarhizium anisopliae for tsetse flies (Glossina spp.) at developmental sites. J Invertebr Pathol 66:237-241.

Kalsbeek V, Mullens BA, Jespersen, JB (2001) Field studies of Entomophthora (Zygomycetes: Entomophthorales) - induced behavioral fever in Musca domestica (Diptera: Muscidae) in Denmark. Biol Control 21:264-273.

Lekimme M, Mignon B, Tombeux S et al. (2006) In vitro entomopathogenic activity of Beauveria bassiana against Psoroptes spp. (Acari: Psoroptidae). Vet Parasitol 139:196202.

Luz C, Fargues J (1997) Temperature and moisture requirements for conidial germination of an isolate of Beauveria bassiana, pathogenic to Rhodnius prolixus. Mycopathologia 138:117-125.

Milner RJ, Huppatz RJ, Swaris SC (1991) A new method for assessment of germination of Metarhizium conidia. J Invertebr Pathol 57:121-123.

Mwamburi LA, Laing MD, Miller R (2010) Laboratory screening of insecticidal activities of Beauveria bassiana and Paecilomyces lilacinus against larval and adult house fly (Musca domestica L.). Afr Entomol 18:38-46.

Nicholson WL, Munakata N, Horneck G et al. (2000) Resistance of Bacillus endospores to extreme terrestrial and extraterrestrial environments. Microbiol Mol Biol Rev 64:548-572.

Olesen US (1985) Effect of humidity and temperature on Entomophthora muscae infecting the house fly, Musca domestica and the increase of survival of the fly by behavioural fever. MSc Dissertation, University of Copenhagen, Denmark.

Prasad R (1994) Influence of several pesticides and adjuvants on Chondrostereum purpureum-a bioherbicide agent for control of forest weeds. Weed Technol 8:445-449. 
Roberts DW, Campbell AS (1977) Stability of entomopathogenic fungi. Misc Publ Entomol Soc Am 10:1-80.

Santoro PH, Neves PMOJ, Alexandre TM et al. (2008) Selection of Beauveria bassiana isolates to control Alphitobius diaperinus. J Invertebr Pathol 97:83-90.

Sokal RR, Rohlf FJ (2012) Biometry: the principles and practice of statistics in biological research. 4th edition. WH Freeman and Co. New York, 937 pp.

Vestergaard S, Gillespie AT, Butt TM et al. (1995) Pathogenicity of the hyphomycete fungi Verticillium lecanii and Metarhizium anisopliae to the western flower thrips, Frankliniella occidentalis. Biocontrol Sci Technol 5:185192.
Watson DW, Mullens BA, Petersen JJ (1993) Behavioral fever response of Musca domestica (Diptera: Muscidae) to infection by Entomophthora muscae (Zygomycetes: Entomophthorales). J Invertebr Pathol 61:10-16.

Watson DW, Geden CJ, Long SJ et al. (1995)Efficacy of Beauveria bassiana for controlling the house fly and stable fly (Diptera, Muscidae). Biol Control 5:405-411.

Zhang W, Wolf TM, Bailey KL et al. (2003) Screening of adjuvants for bioherbicide formulations with Colletotrichum spp. and Phoma spp. Biol Control 26:95-108.

Associate Editor: Lara Durães Sette

All the content of the journal, except where otherwise noted, is licensed under a Creative Commons License CC BY-NC. 